\section{A meaning-based framework for customer loyalty}

\author{
Elina Närvänen and Hannu Kuusela \\ Faculty of Management and Business, Tampere University, Tampere, Finland \\ Heli Paavola \\ Faculty of Management and Business, Tampere University, Tampere, Finland and \\ Witmill Ltd, Tampere, Finland, and \\ Noora Sirola \\ Faculty of Management and Business, Tampere University, Tampere, Finland
}

A meaningbased framework for customer loyalty

\footnotetext{
Received 7 May 2019

Revised 31 May 2019 10 June 2019 17 June 2019

22 January 2020

23 January 2020

Accepted 30 April 2020
}

\begin{abstract}
Purpose - This paper's purpose is to develop a meaning-based framework for customer loyalty by examining how consumers make sense of customer loyalty through meanings and metaphors.

Design/methodology/approach - A qualitative study based on in-depth interviews and focus group data in the retail context was conducted with Finnish customers. The data were analysed with qualitative data analysis techniques such as the constant comparative technique.

Findings - The empirical findings comprise eight loyalty meanings characterised by two dimensions. The first dimension is reflexive vs. routinised, and the second dimension is private vs. social. The loyalty types are dimensionalised through four metaphors: loyalty as freedom of choice; as being conventional and binding; and as belongingness.

Practical implications - The findings improve the way customer loyalty currently is understood in the retail setting. The paper proposes that customer insight that utilises thick data can be used to grasp loyalty meanings. These data are rich in context and detail, and they take into account customers' everyday lives. Utilising thick data in the form of storytelling fuels customers' meaning-making related to customer loyalty, potentially enriching their relationship with the retailer.

Originality/value - Customer loyalty has been driven largely by a transactional and company-centric perspective. This article presents an alternative view of customer loyalty that accounts for the variety of meanings that customers may assign to their loyalty-related thoughts and behaviours.
\end{abstract}

Keywords Customer loyalty, Meanings, Interpretive, Interviews, Thick data

Paper type Research paper

\section{Introduction}

How to retain profitable customers and increase customer loyalty is an enduring concern for retailers. In the current competitive, omnichannel environment, in which switching costs are low and customers can compare retailers' offerings and price levels more transparently (Grewal et al., 2017), customer loyalty increasingly seems to be more difficult to achieve (YouGov, 2018). Still, customer loyalty often is regarded as one of the key outcomes of a successful customer relationship management programme (Uncles et al., 2003; Nastasoiu and Vandenbosch, 2019). In the retail context, in which customers purchase repeatedly, understanding customer loyalty and how to influence it is essential (Rundle-Thiele, 2005; Orth and Green, 2009; Pan et al., 2012).

C Elina Närvänen, Hannu Kuusela, Heli Paavola and Noora Sirola. Published by Emerald Publishing Limited. This article is published under the Creative Commons Attribution (CC BY 4.0) licence. Anyone may reproduce, distribute, translate and create derivative works of this article (for both commercial \& non-commercial purposes), subject to full attribution to the original publication and authors. The full terms of this licence may be seen at http://creativecommons.org/licences/by/4.0/legalcode.

The authors want to thank the anonymous reviewers for their constructive comments on the manuscript.

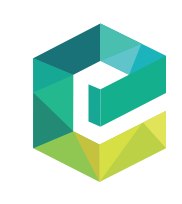

International Journal of Retail \& Distribution Management Emerald Publishing Limited DOI 10.1108/IJRDM-05-2019-0153 
Customer loyalty, as a theoretical construct, also has been recurring in extant retailing and marketing literature (e.g. Pan et al., 2012; Kumar et al., 2013; Audrain-Pontevia and Vanhuele, 2016). Loyalty, according to Watson et al. (2015), based on a meta-review of previous research, is 'a collection of attitudes aligned with a series of purchase behaviours that systematically favour one entity over competing entities' (p. 803). However, loyalty most often has been defined from the company's perspective, and in extant literature, it has been discussed as a dependent variable (i.e. as an outcome) rather than examining the construct on a deeper level from the customer's perspective.

This article builds an alternative approach to customer loyalty by drawing from the sensemaking perspective (Weick, 1995; Woodside, 2001). This perspective is rooted in the basic assumption that people are storytellers and use meanings to interpret the surrounding world and their own identities (Polkinghorne, 1988; Bruner, 1990; McAdams and McLean, 2013). For customers, loyalty is a multidimensional, context-bound and dynamic concept (Pan et al., 2012) that can be experienced in various ways, just as human memory is constructed on stories (Thompson, 1997; Woodside, 2010). The sensemaking approach (Woodside, 2010) allows for further analysis of under-theorised aspects. It also focuses on how people 'go about selecting relevant elements in their worlds and combine these elements to create a perceived reality' (Woodside, 2001, p. 5). Metaphorical thought also can drive behaviour, which is why it is important to understand the metaphors that customers use to describe customer loyalty (Gilliam and Rockwell, 2018). From this perspective, this paper addresses the following research questions:

$R Q 1$. What kinds of meanings do customers construct to make sense of customer loyalty?

RQ2. What kinds of loyalty metaphors can be identified in customers' sensemaking?

In the theory section, we outline a meaning-based view of customer loyalty. In the method section, we detail the interpretive approach and the research design. In the results section, the loyalty dimensions are introduced, together with the eight meaning-based loyalty types constructed from the data. Finally, we address the theoretical and managerial implications of the research, as well as suggest future research directions.

\section{Toward understanding customer loyalty on a deeper level}

Historically, the customer loyalty construct was defined as frequent purchasing, but literature has since evolved to consider multiple dimensions, including behavioural, attitudinal and composite (for a review, see Yoo and Bai, 2013). The attitudinal component has been defined as 'a deeply held commitment to repurchase a specific product, service or brand' (Oliver, 1999, p. 306), and it has been related to an emotional and psychological sense of commitment and attachment (Sirohi et al., 1998; Aksoy et al., 2015). Behavioural loyalty refers to indicators such as repeat purchases, share-of-wallet or purchase longevity and frequency (Yoo and Bai, 2013). Finally, recent articles on customer loyalty (Kumar et al., 2013; Liu-Thompkins and Tam, 2013; Watson et al., 2015; Wolter et al., 2017) have emphasised the composite view. A debate also has developed on the antecedents of customer loyalty, ranging from customer satisfaction to trust and commitment (Pan et al., 2012; Yoo and Bai, 2013; Nyadzayo and Khajehzadeh, 2016), and more recently, customer engagement (So et al., 2016). However, in these debates, customer loyalty today often is being discussed as a dependent variable (i.e. as an outcome) rather than attempting to understand its nature as a multifaceted construct, especially from the customer's perspective.

The development of customer loyalty, from Oliver's (1999) conceptualisation onward, has been viewed as an evolutionary and incremental process that begins with rational, logical reasons (cognitive loyalty), then shifts to emotional attachment (affective loyalty) and finally to behaviour (conative loyalty and action) (see also Fraering and Minor, 2013). In the final 
stage, the consumer is willing to repurchase from the company, despite situational barriers or competitive offerings that potentially could change the consumer's behaviour (Oliver, 2010). This evolutionary process also has been conceptualised as a framework of loyalty conditions (Dick and Basu, 1994). For instance, Folkman Curasi and Kennedy (2002) offered a typology of consumers from 'prisoners' to detached loyalists, purchased loyalists, satisfied loyalists and apostles. According to a recent empirical study, consumers move from one loyalty stage to another over time, and marketing actions can be used to influence this process (Ngobo, 2017).

Furthermore, in the retail setting, store image (Orth and Green, 2009), perceived quality and other features of the retailer's reward programme, emotional attachment to the programme (Vilches-Montero et al., 2018) and a stronger retailer brand image have been suggested as possible positive influences for customer loyalty (Nyadzayo and Khajehzadeh, 2016). A study by Rundle-Thiele (2005) in a retail context suggested that six dimensions beyond behavioural and attitudinal loyalty characterise customer loyalty, including citizenship behaviour, different types of complaints, propensity to be loyal and resistance to competing offers. The psychological, or cognitive, perspective still heavily underlies these dimensions (e.g. Umashankar et al., 2017). Furthermore, these conceptualisations do not explain what loyalty means to consumers.

Many researchers have suggested that loyalty is context-specific, as it is personal (Folkman Curasi and Kennedy, 2002) and also depends on market and industry characteristics, such as competition, switching costs (Blut et al., 2014; Ngobo, 2017) and what customers actually are loyal toward (e.g. company, employees, brand, brand community) (Aksoy et al., 2015). This perspective broadens the perspective in which customers' relationships with a single company and their relationships with other customers in a community are viewed (McAlexander et al., 2002). Thus, loyalty can be conceptualised as a shared experience, as well as a personal one.

To summarise, previous customer-loyalty research has viewed it as a hierarchical, incremental and cognitive phenomenon. This approach has not acknowledged customer loyalty as a sensemaking phenomenon, in which consumers actively engage in ascribing meaning to loyalty in different situations (Richins, 1994; Thompson, 1997; Woodside, 2001).

\section{Sensemaking through storytelling and metaphors}

Woodside (2001, p. 416) defines sensemaking as: 'meaning creation based on current and prior interpretations of thoughts generated from three sources: external stimuli; focussed retrieval from internal memory; and seemingly random foci in working memory. Such sense making is constructed on cultural pilings held unconsciously in long-term memory'. Furthermore, he connects sensemaking with identity construction and social interaction, and sees it as a continuous dynamic process. Researchers in management studies have connected sensemaking with storytelling (Brown et al., 2015). McAdams and McLean (2013) argue that for humans, storytelling is a central mechanism through which we assign meaning to our lives and our own identities.

The storytelling perspective has been adopted in retailing research to study how stories and metaphors may be utilised in sales encounters (Gilliam and Zablah, 2013; Gilliam and Rockwell, 2018). Stories denote a temporal, sequential structure in sensemaking, whereas metaphors refer to how sensemaking is made concrete through juxtaposition of something strange or new with something familiar (Gilliam and Rockwell, 2018). Thus, by utilising these elements, retailers may communicate with customers in more relevant and affective ways that resonate with consumers' everyday lives. Stories also have been used in retail branding (Woodside, 2010; Chiu et al., 2012), as well as in creating branded store servicescapes and experiences (Kozinets et al., 2002; Borghini et al., 2009), and in understanding how consumers 
experience multichannel shopping (Harris, 2017). Through investigating the kinds of stories customers tell about customer loyalty, it is possible to access a more multifaceted view of customer loyalty in the retail setting, as well as the underlying meanings for customers themselves.

\section{Methodology}

To examine how consumers themselves make sense of customer loyalty, we adopted an interpretive approach, in which consumers are perceived to create, modify and combine meanings of customer loyalty in an active process through language (Thompson, 1997). This is how consumers make sense of what customer loyalty means to them in their daily lives (Woodside, 2001). Thus, sensemaking can be defined as meaning creation (i.e. denoting how consumers use language to describe what things and phenomena in their surrounding world mean to them). Meanings can be personal (e.g. a customer may feel nostalgic toward a specific store where he or she had been a customer during his or her childhood) or public (e.g. a store may use symbols of nostalgia, such as old music or retro visuals in its advertising, to transport customers back to the past) (Richins, 1994). However, whether customers successfully interpret these meanings depends on customers' sensemaking in the context where they encounter the store or advertising. The analytical units are the dynamic and context-dependent meanings through which consumers relate to customer loyalty in the data.

The research process followed the Gioia method's general principles (Gioia et al., 2013). It is inspired by grounded theory and is well-suited for explaining how customers make sense of loyalty in their own words. The method comprises the following steps: (1) research design (choosing a 'how' type research question that focuses on revealing relations between concepts and consulting existing literature with an open mind); (2) data collection (giving informants opportunity to talk about the phenomenon of interest in their own words); (3) data analysis (initial data coding to preserve informants' true voices and second-order coding to arrive at more abstract, theory-centric themes and dimensions, assembled into a data structure [Figure 1]); and (4) grounded theory articulation (formulating dynamic relationships among the second-order concepts in the data structure [Figure 2] and relating the theory with the literature) (Gioia et al., 2013).

The study's data comprise in-depth interviews $(n=13)$ conducted during the study's first phase, as well as a focus-group interview $(n=12)$ conducted during the study's second phase. The interviewees were recruited using theoretical sampling and were selected because they were particularly apt at generating insights about the customer-loyalty phenomenon (Eisenhardt and Graebner, 2007). The customers' contact details for the interviews were procured from one of Finland's biggest retail-chain's customer database of loyalty-card holders. The S-group is an international, multi-format, multi-industry grocery retailer and service provider with the greatest market share $(46.4 \%$ in 2018$)$ in grocery retailing. Therefore, using its customers as informants for the study allowed for enough depth, history and diversity of experiences related to customer loyalty. The customers were sent invitations to participate in the research if they viewed themselves as loyal customers to the said chain. First-phase interviewees' demographic data are provided in Table 1. We obtained a varied sample of people of different ages, occupations and genders for the study. This assures that there is sufficient variety in the loyalty stories of interviewees, even though the aim of this qualitative study is not to generalise from the sample, but to explore similarities and common meanings and metaphors in the loyalty narratives of consumers.

The interviews were conducted at participants' homes or at the interviewer's office (two cases). In qualitative research, the number of interviewees is not as crucial as the saturation of the data (i.e. when the data reach a point at which no significant or new insights emerge) (Glaser and Strauss, 1967). This saturation was reached in this study, as evidenced by the frequency of themes in the interviews (see Figure 1). The interviews were both open and 


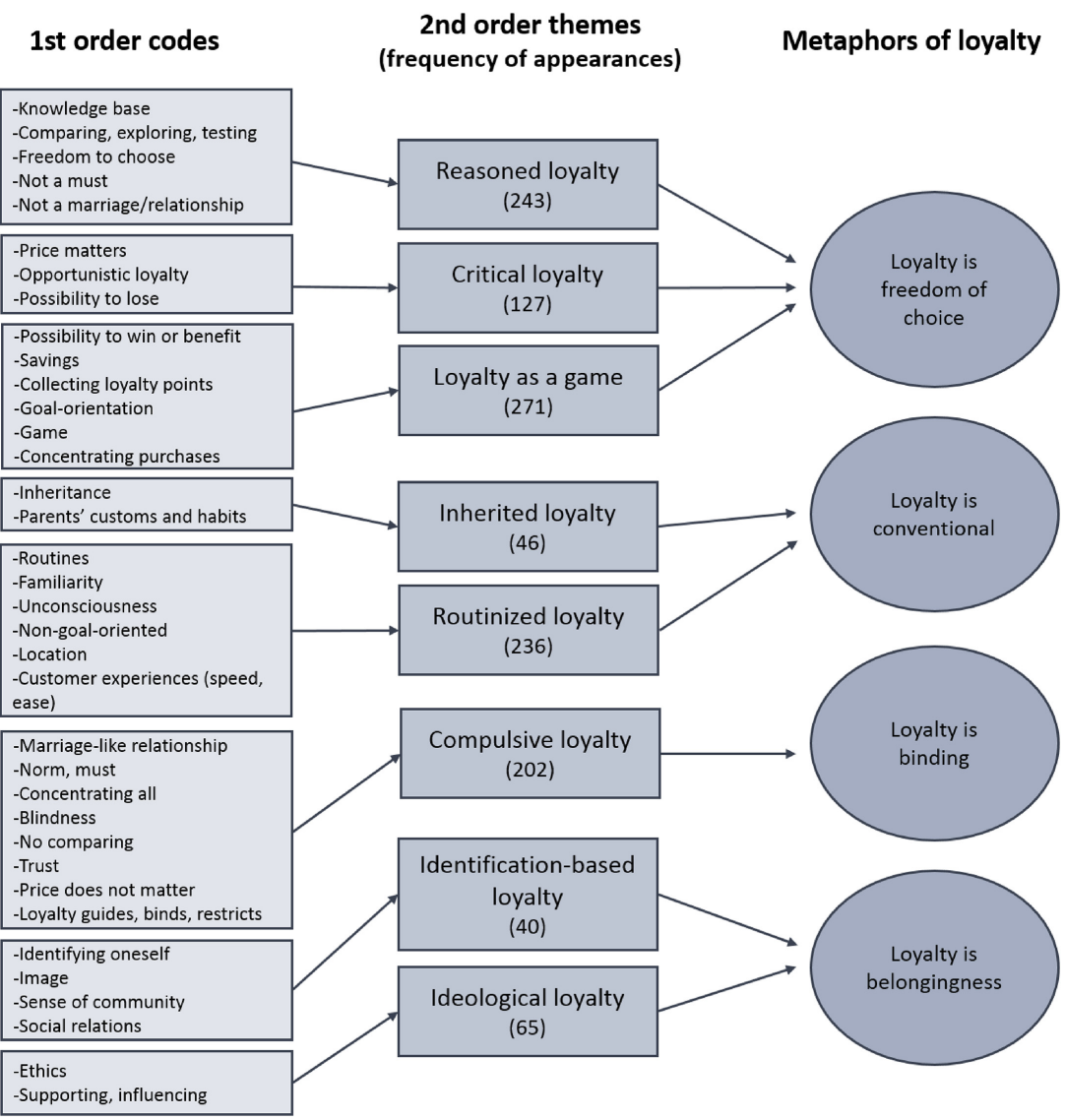

A meaningbased framework for customer loyalty
Figure 1. Structure of the data

reflective. The interview began with broad questions concerning each interviewee's life story, then moved to questions about customer loyalty, including: 'What is a loyal customer like?' 'How are you a loyal customer?' 'Why are you loyal?' 'How does loyalty feel?' 'Why is it important to you to be loyal?' 'What does it mean for you personally to be loyal?' The interviews took between 30 and 90 min each and were recorded and transcribed in detail, totalling 130 pages of text.

First, the data were read carefully, and terms and categories were identified inductively. Variations of these comprised closely related, focussed, internally coherent and concrete thematic wholes, which were identified, yielding 300 interviewee codes. Multiple rounds of constant comparison (Gummesson, 2006), in which smaller fragments of data (codes) were compared with larger wholes (emerging themes) and back again (Creswell, 2007), and abstraction yielded 36 first-order codes that were classified into eight second-order themes comprising eight loyalty types (see Figure 1). These were constructed by analysing the interrelationships between first-order codes. These loyalty types were integrated into four loyalty metaphors to explain and describe loyalty from a customer's perspective (Gioia et al., 2013). 


\begin{tabular}{|c|c|c|c|c|}
\hline \multirow[t]{7}{*}{ IJRDM } & Interviewee (gender) & Age & Occupation & Household size \\
\hline & Aino $(F)$ & 64 & Retiree & 1 adult \\
\hline & Anna (F) & 29 & Student & 2 adults \\
\hline & Elli (F) & 62 & Retiree & 2 adults \\
\hline & Liisa $(F)$ & 55 & Unemployed & 3 adults \\
\hline & Maija (F) & 56 & Senior officer & 2 adults \\
\hline & Tuula (F) & 56 & Teacher & 1 adult \\
\hline \multirow{7}{*}{$\begin{array}{l}\text { Table 1. } \\
\text { Interviewee } \\
\text { demographics }\end{array}$} & Ilkka (M) & 63 & Retiree & 2 adults \\
\hline & Juha (M) & 26 & Student & 1 adult \\
\hline & Matti (M) & 65 & Retiree & 1 adult \\
\hline & Mikko (M) & 25 & Student & 2 adults \\
\hline & Sami (M) & 36 & Cashier & 2 adults, 1 child \\
\hline & Timo (M) & 44 & Artist & 2 adults, 2 children \\
\hline & Veijo (M) & 37 & Researcher & 1 adult \\
\hline
\end{tabular}

During the study's second phase, a focus-group interview was conducted with 11 consumers ages 22 to 38 to further review and verify the relevance of the earlier stage's findings, which is an established approach in qualitative management and marketing research (Töytäri et al., 2015). This group's members were recruited using the researchers' personal contacts. One of this study's authors moderated the focus-group interview, which lasted 96 min and was conducted at the university in December 2019. The focus group first discussed the topic of customer loyalty in a general manner (e.g. 'What does customer loyalty mean to you?' 'Are you, yourself, loyal to a store?' 'How does that show in your thoughts or behaviour?'), then the group discussed each of the eight loyalty types identified in the earlier analysis in more detail. The discussion largely validated the findings from the study's first phase, as the participants were able to identify each loyalty type. However, the focus-group discussion enabled the researchers to strengthen the themes with new examples of meaning-making related to them.

\section{Findings}

First, the data were dimensionalised according to whether the meanings of customer loyalty were more reflexive or habitual in nature. Researchers recently have highlighted the role of habits in developing customer loyalty (Uncles et al., 2003; Olsen et al., 2013; Liu-Thompkins and Tam, 2013). Positive experiences in the past may lead to developing habits that continue without conscious reflection. Most consumer behaviour revolves around routine and is quite automatic in nature. For instance, Liu-Thompkins and Tam (2013, p. 22) define habit as 'a behavioural disposition that is exercised frequently and in which responses are triggered directly by contextual cues. In opposition to this, reflexive loyalty is the consequence of conscious reasoning and characterised as a deliberate choice. Second, we focussed on whether the meanings generated during the interviews were more private (inward-facing) or sociocultural (outward-facing) in nature (Richins, 1994; Thompson, 1997). Private meanings are more idiosyncratic and are the sum of the subjective meanings that objects hold for a particular individual' (Richins, 1994, p. 506). Here, the consumer's personal history plays a role (Thompson, 1997), even though private meanings also are represented in the interview situation through shared language and, therefore, are not completely unique. Richins (1994, p. 506) has defined public meanings as 'subjective meanings assigned to an object by outside observers ... members of society at large' and largely are shared in society. These meanings are constructed socioculturally and highlight people's social relations, status and sense of belonging to various groups. This categorisation resulted in a two-by-two matrix in which we positioned the themes identified in the data. Next, we discuss these themes in more detail. 


\subsection{Reasoned loyalty}

The theme of reasoned loyalty involves aspects related to the freedom to choose as a customer. Consumers are aware of their rights to compare and evaluate retailers as part of becoming loyal customers. Reasoned loyalty also relates to people's need to feel that they are acting as rational and sensible beings. The focus-group interviewees also talked about the retailer reinforcing this feeling for the customer:

The retailer needs to show that you are free to choose, but you are choosing right. . ..that you are not choosing wrong. You are not making an insensible decision (Jarno, male focus-group participant).

Reasoned loyalty is based on meanings of optimising, making sensible choices and exercising freedom of choice. The interviewees described this type of loyalty as being built through experiences and knowledge gained through purposefully comparing alternatives. They depicted making comparisons between different companies or products and 'doing tests' to find the best alternative (i.e. the one that elicits loyalty). Paying attention to prices was central to reflections regarding reasoned loyalty, but other aspects such as quality were mentioned as considerations when aiming for the optimal choice. Continuous comparisons and satisfactory experiences were viewed as gradually creating trust and encouraging loyalty towards a retailer - eventually no longer requiring comparisons:

Well, I have done a test when there's been roast beef in discount. I have bought a smaller amount of it and tried to make some meat sauce, and there's so much fat in it ... In their [other retailer's] one, there's not ... So, in that sense, I have done these tests. It's not so that I always and exclusively go to that store. I do compare, buy small amounts from different stores, compare and look ... So that way [... ] I have ended up buying from there. [. . . I've never had bad [meat] from there, from some other place I have (Aino, female interviewee).

Being aware of available alternatives was discussed as a characteristic of reasoned loyalty. However, in this loyalty type, the loyal customer was no longer interested in switching after realising a competitor's low price-quality ratio. The interviewees described a situation in which, after several tests, the comparisons would become unnecessary (i.e. the loyal customer eventually would be able to trust the company with the certainty that it was the best choice). Loyalty was presented as a reasoned choice, and the freedom to be disloyal was constructed as an important aspect of reasoned loyalty. No emotional bond between customer and company was constructed in the interviewees' speech in relation to reasoned loyalty. Instead, being loyal made sense, as it was beneficial for the customer. Moreover, if it turned out not to make sense, a loyal customer still was presented by the interviewees as being free to choose otherwise.

\subsection{Critical loyalty}

Critical loyalty builds on high price sensitivity, scepticism towards companies, multi-loyalty and fear of losing money as a result of not making the best economic choices. Purchasing exclusively from one company (i.e. blind loyalty) was presented as economically risky and unwise. The need to check prices and compare alternatives constantly represented doubt towards retailers, even if they provided a good earlier alternative, thereby making loyalty superficial and sceptical. This kind of scepticism also was visible in the interviewees' beliefs that all extra benefits, such as loyalty-programme points, would result in higher prices because of the company's need to make a profit. Regardless of high price sensitivity and suspicion, critical loyalty was presented as one form of loyalty in which a certain company was chosen, but only when it was optimal in terms of money:

I'm a critical customer. I know if you buy everything from the same firm without comparing prices in other firms, you eventually pay extra. [... . My loyalty is that I buy things that I need from there [the 
store] when it's the best alternative for me. I'm not ready to pay extra just because I'm a loyal customer (Sami, male interviewee).

In critical loyalty, price was viewed as the ultimate criterion for both purchasing and loyalty decisions. Paying constant attention to prices represented a customer's inability and unwillingness to trust companies. This seemed to be a way to save money and reduce the financial risk present in all purchasing decisions. Trusting companies by not checking alternative prices - and as a result, paying extra for being loyal - was viewed as unwise or even stupid. Critical loyalty also was constructed by being 'multi-loyal'. This aspect was discussed in the focus-group data:

I wonder, can you be loyal to one brand or store? Can you be loyal to different stores, competing stores at the same time? I do consider myself as loyal to many at the same time (Harri, male focusgroup participant).

Combining all possible customer-loyalty programmes was discussed as the best way to utilise each company's offerings (i.e. being loyal to what is best for you in each situation). The focus-group members also reflected on income levels' influence on loyalty. Critical loyalty was described as a growing trend, as it was viewed as a strategy to generate loyalty in younger generations (millennials and Generation $Z$ ) of consumers whose income generally is smaller than that of their parents, as they cannot 'afford' blind loyalty. Critical loyalty is about limited loyalty, or as one focus-group interviewee described it, loyalty with some 'boundaries':

I think that it [critical loyalty] is about loyalty with certain boundaries. You are loyal if it stays within your limits. For instance, you are generally loyal to an airline, but then if their prices suddenly climb so high that you lose hundreds of euros if you remain loyal, then you switch (Emma, female focusgroup participant).

\subsection{Loyalty as a game}

Loyalty can resemble playing a game. This type of loyalty is based on winning, saving money and gaining various benefits in everyday life through smart consumption decisions. Loyalty and belonging to loyalty programmes were presented as ways to attain monetary benefits and other rewards. They were viewed as being important, especially when making bigger purchases or several purchases within a short time frame. Loyalty was constructed as a goal-oriented activity:

My loyalty is about collecting loyalty programme points by concentrating the purchases. [...] It's sort of a game (Liisa, female interviewee, 55).

Thus, concentrating one's purchases on one company represented a way to utilise the benefits of loyalty, especially loyalty programmes. Some of the interviewees discussed prepurchasing or postponing purchases to maximise monthly paid loyalty-programme points and reap monetary benefits. Concentrating one's purchases was viewed as smart and a way to do well in the game. The profits from loyalty and concentrated buying were highlighted, especially in terms of the most significant purchases, even though it also was common to make smaller purchases from other companies:

Well, it provides a possibility to win [. . . because I have to buy it somewhere anyway . . . and then I notice how there's Finnish products for a competitive price so why would not I . . . And you get those loyalty programme points, always a few free cents (Matti, male interviewee).

You can calculate and optimise - for instance, you can check to see if you can get the things you want for cheaper if you concentrate all purchases to one store rather than buying everything separately (Heini, female focus-group participant). 
During the interviews, loyalty-programme rewards were presented as being equal to free extra money and savings without any extra effort. The amount of actual monetary savings was small, but these small wins seemed to create feelings of pleasure, making loyalty worth that extra effort. Like games, loyalty's benefits went beyond merely saving money. Planning and optimising shopping seemed to create excitement, joy and feelings of success because of the achieved monetary benefits. Multi-loyalty also was discussed, but in contrast to critical loyalty and doubt, it was presented as an opportunity to cherry-pick and always get the feeling of winning. Loyalty also was associated with the idea of a 'card game', in which the loyalty card of the optimal company was selected for each purchasing decision. Focus-group participants also discussed whether loyalty as a game was very superficial in nature, which would encourage consumers not to be loyal, but instead focus solely on price. On the other hand, they also perceived that not many retailers are utilising their loyalty programmes' gamification potential to its full extent:

- I do not think getting bonus points really is about gaming. For instance, playing a game always involves some goals and reaching new levels (Joni, male focus-group participant).

- Yes, there are now these initiatives where retailers are giving you data about your purchases, for instance, how much toilet paper you are using in kilometres per year. . it is fun, but it is still in its baby steps, I think. You need a 'catch' to motivate you to play the game (Jarno, male focus-group participant).

- Yes, why do not they launch something like Pokémon Go for their stores ... I know I would be playing that all the time (Joni, male focus-group participant).

\subsection{Inherited loyalty}

Inherited loyalty builds on meanings of nostalgia, appreciating the choices of one's parents and following the values and customs inherited from the family. In some of the interviewees' reflections, loyalty was based on childhood experiences and was viewed as following a custom formulated as a child:

I think that when customer loyalty has been inherited in the family for generations, it's obvious, you do not question it, you do not even think about it. [. . . It feels reasoned, and it works, the relationship with the firm, and in a way, you were born into that, raised to be a loyal customer [. . . it feels obvious, and you do not question it (Sami, male interviewee).

The nostalgia aspect also was identified in some interviewees' reflections: Visiting the same companies as one's parents or grandparents was viewed as fun and meaningful:

Like, you really visit the same meat shop your grandfather already visited [laughing] (Veijo, male interviewee).

Loyalty was presented as originating in one's upbringing, in which the customer automatically continues learned habits into adulthood. However, the focus-group participants also discussed how their loyalty could change and evolve as a result of more conscious deliberation in adulthood as they become independent and in charge of their own spending:

-You are somehow pushed in that direction, if your parents have been loyal to some company, it has been the only thing you've known, but now that you have the freedom to choose, you can put your own money where you want. Of course, you start to think it through more carefully (Joni, male focusgroup participant).

- Yes, the inherited loyalty is not necessarily as strong as something that you have chosen on your own, based on your own values (Heini, female focus-group participant).
A meaningbased framework for customer loyalty

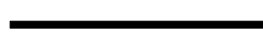


Routinised loyalty is constructed from the meanings of familiarity, convenience and safety. Loyalty is sustained by the ease of always visiting the same company. The interviewees reflected on the speed and ease of shopping in a familiar store, in which you can be certain that you will get what you need. The lack of effort in the decision-making process and the overall shopping experience highlight the benefits of sustaining one's routine and being loyal:

You are used to going there and always find what you are looking for. I also remember the things I was supposed to buy much better when I go to a familiar store where I know where everything is located, compared to an unfamiliar one, where you have to look for things (Elli, female interviewee).

A familiar store was perceived as creating feelings of security and making the buying process effortless. A good selection of products, the ability to find what you need, friendly staff, pleasant lightning and good facilities represented reasons for building one's routine. In the interviews, customers said that visiting a familiar retailer was simply more pleasant and a nicer experience. Loyalty itself was not considered the goal, but rather, the comfortable, functional routines represented the reasons to want to visit a certain retailer repeatedly.

In the analysis, routinised loyalty was identified as being connected with other routines of everyday life, and the interviewees discussed the significance of choosing or 'ending up with' the company to which one is loyal. It was viewed as relevant that the store be located along one's everyday transport routes. However, this was not viewed as an exclusive criterion when choosing an object of loyalty. The interviewees also discussed how, in some cases, traveling a bit further to be able to conduct familiar routines could be more convenient than visiting the closest store. Routinised loyalty also caused opinion differences in the focus-group data, as not all participants really viewed it as loyalty, as it is not a conscious choice:

I do not know whether you can even call it loyalty? Is it part of loyalty if you always go to a certain store? Do you think you feel a commitment then or not? Is it true loyalty then? For me, loyalty is also about a psychological commitment, rather than only action (Rosa, female focus-group participant).

This quotation shows that from the customer's perspective, a negotiation process always is underway on the meanings of loyalty, and it is a subjective, context-dependent matter.

\subsection{Compulsive loyalty}

Compulsive loyalty is based on meanings of strong commitment and obligation, as well as a marriage-like personal relationship with a company. This kind of loyalty may resemble an absolute, exclusive and binding relationship that controls the consumer's consumption choices. Some interviewees compared customer loyalty to marriage and explained how a loyal customer exclusively would be obliged to support and visit one company. On the other hand, many positive sides to being 'married' also exist. Even though a marriage-like relationship with a company can be binding and contain negative features, it also was perceived as making shopping simpler, as customers can trust their partners to be the best alternatives during good and bad times. However, being disloyal was perceived as causing feelings of guilt and a bad conscience. It was presented as socially and morally unacceptable, comparable to cheating:

Yes, I must say it means quite a lot, like I said, I do not go goofing around. Yes, I mostly concentrate on that [a company]. It really is so, that you should concentrate [purchases] and be loyal to the one you have joined (Aino, female interviewee).

This kind of loyalty also may turn into an obsession. One interviewee reflected on visiting a grocery store she was loyal to every day of the week, and even multiple times a day if she forgot to buy something during her earlier visits. This obsessive nature in relation to loyalty also was present in discussions about how one should make even the smallest purchases in a 
store they were loyal to, even if another store was closer. Commitment to only one business was viewed as a virtue.

The negative, controlling and binding aspects of this kind of loyalty also were identified in the analysis. The interviewees brought up the burden of ending up with a reduced variety of alternatives. One interviewee viewed it as forced loyalty:

A meaningbased framework for customer loyalty

Maybe it [loyalty], at its purest, is like, always choosing it, always going there. And on one hand, it restricts your options if the company does not have as many alternatives as you imagine [...] it restricts your choice that you have to go there just because of that [loyalty] (Sami, male interviewee).

Thus, compulsive loyalty may appear to be total blindness to other alternatives and ultimate trust in a single company. A loyal customer was presented as not even looking at other companies' ads or comparing prices. For the focus-group participants, many of whom were part of the younger millennial generation, this binding nature of customer loyalty was viewed as a 'worst case scenario', and some perceived it as not even part of true customer loyalty:

- To me, it is not a part of loyalty that you stay passively in a bad situation. Instead, it is like choosing the one you want to be with again and again every day (Heini, female focus-group participant).

- For me, compulsive loyalty is a stage where you are already stepping away from being a loyal customer (Marko, male focus-group participant).

- I think that it can be considered a negative aspect if new customers look at existing customers' relationships with the company and think that if I buy from that retailer, then I have to commit to them forever' - it is not an attractive option then (Jarno, male focus-group participant).

Thus, the consumers recognised, in their sense-making, the dynamic and processual nature of customer loyalty as something that can shift and change, and as something that should be mutually beneficial, rather than forced upon them.

\subsection{Identification-based loyalty}

Identification-based loyalty is based on meanings of togetherness, identifying oneself and belonging to a community: Being loyal is a way to feel and express who you are and where you belong. This could be observed in interviewees' reflections on feelings of togetherness when visiting a familiar company and identifying oneself with other customers. Being loyal was associated with the idea of belonging to the same group with other customers, which made shopping meaningful and more than just carrying out one's everyday routine:

I feel more like home here; it's like I think I'm with my people. I feel like it's my home. Of course, I recognise the faces, notice that there are the same people shopping there regularly ... There's this small difference; it's nicer to go there (Liisa, female interviewee).

The interviewees also discussed loyalty as a way to widen and maintain social relations in everyday life. Identification-based loyalty goes beyond functional meanings. Both the staff's familiar faces and the feelings of togetherness were viewed as making loyalty socially meaningful to the customer.

Loyalty also was discussed as being based on the 'fit' between one's identity and the company's image. Some interviewees discussed certain stores looking 'just like them', and they even talked about 'their store'. The interviewees also reflected on how the company's image also may match a loyal customer's desired self-image and lifestyle. Thus, loyalty represented a way in which to build and maintain a preferred identity and show this to other consumers. For example, one interviewee reflected on customers whom she felt were loyal to a certain department store just to be seen there and to appear as having higher status in the eyes of fellow customers. However, the focus-group members discussed identification-based loyalty as sometimes choosing a retailer to oppose or avoid another: 
It can be about a kind of reverse loyalty as well. I am kind of loyal to one company in order to avoid another (Marko, male focus-group participant).

This may occur because the consumer may not want to be associated with a certain lifestyle or consumer group associated with a particular retailer.

\subsection{Ideological loyalty}

Ideological loyalty builds on meanings of being socially active and making an impact through one's consumption decisions. Loyalty is represented as a way of expressing one's ethical values and political opinions. During the interviews, the acknowledged power of everyday choices and the opportunity to make a difference were viewed as encouraging loyalty. Customer loyalty was constructed as a purposive act:

I try to buy fair-trade bananas. [.. . ] In that sense, I'm loyal because it's so great ... The fair-trade system. It needs people's support. Even though they cost more, I still try to buy them. The system is still fairly new, so it cannot function that effectively and produce food at the same cost, so in that sense, you have to support it (Mikko, male interviewee).

Thus, customer loyalty was viewed as a way to express opinions and show where you stand in relation to various issues. Some interviewees discussed how there was once two kinds of consumers: Those who supported Retailer A and those who supported Retailer B. There was no way you could support both or even think of going to 'the other one'. Therefore, the meaning behind loyalty was viewed as a willingness to show one's opinions to other consumers. The focus group also discussed how ideological loyalty also is dependent on a customer's wealth and income. Being loyal, e.g. by paying more for social or environmental responsibility, can be expensive: 'The more you can afford, the more you can be loyal' (Marko, male focus-group member). Ideological loyalty is constructed by making intentional choices and doing more than what is expected from a customer in the traditional buying role. Loyalty was viewed as being sustained even though it required sacrifices, such as paying a higher price or providing feedback. Loyalty represented a way to influence relevant societal issues, such as ecological sustainability or community welfare. Loyalty's purpose and goal-orientation also was visible in beliefs about an individual's ability to support systems and ideologies by being loyal.

\subsection{Summary of findings}

Next, we summarise and further elaborate on our findings with the help of four metaphors concerning what loyalty means for the customer (i.e. loyalty as freedom of choice, as conventional, as binding and as belongingness) (see Figure 2).

First, in the reflexive and private quadrant, loyalty is based on freedom of choice for the consumer. This metaphor contains the themes of reasoned loyalty, critical loyalty and loyalty as a game. In these themes, the customer makes calculations and deliberately chooses to be (or not to be) loyal. For the customer, being loyal does not mean blind loyalty: Instead, it may mean actively weighing the benefits and costs of being loyal to one company. Customers who make sense of loyalty in this way have been described in previous research as 'detached loyalists or purchased loyalists' (Folkman Curasi and Kennedy, 2002), as they perceive a functional, rather than emotional, bond with the retailer or appreciate the benefits of the retailer's reward programme, resulting in higher switching costs (Blut et al., 2014; Nastasoiu and Vandenbosch, 2019).

Second, in the habitual and private quadrant, loyalty is characterised as being conventional. This metaphor contains the themes of habitual loyalty and inherited loyalty. In these themes, customers are not very reflexive. Instead, they have a habit of being loyal as a consequence of their personal history with the company (Olsen et al., 2013; Liu-Thompkins 


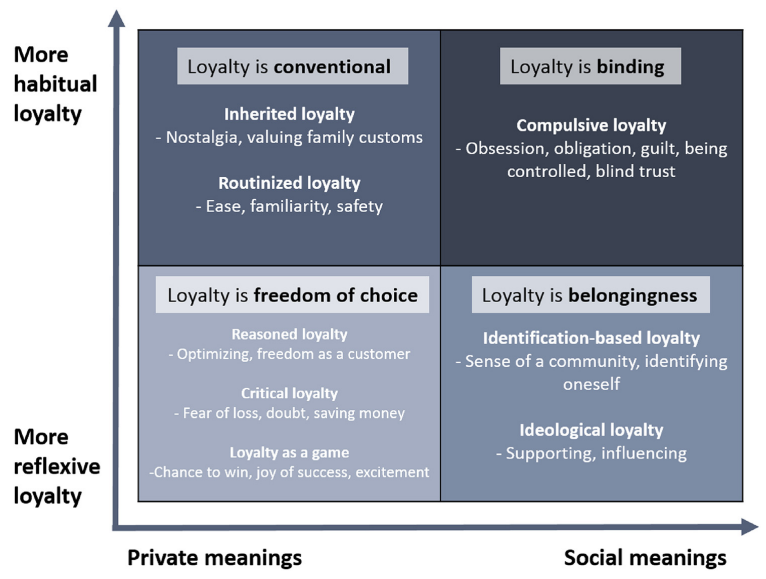

A meaning-
based
framework for
customer loyalty

Figure 2.

Framework of meanings of customer loyalty

and Tam, 2013). The customers who make sense of loyalty in this way have been described as satisfied loyalists (Folkman Curasi and Kennedy, 2002).

Third, in the habitual and social quadrant, loyalty is characterised as being binding. Here, the customer feels obliged to be loyal to the company, as if in a relationship with it. This relationship resembles a human relationship, in which customers feel like they would be sacrificing something if they were disloyal. Thus, the social meanings related to loyalty in human relationships are strongly present in this quadrant (Aksoy et al., 2015). It is also possible for customers who make sense of loyalty in this way to feel like they are trapped in the relationship without any real options to switch (Folkman Curasi and Kennedy, 2002).

Finally, in the fourth quadrant of reflexive and social meanings, loyalty is viewed as belongingness. This metaphor contains the themes of social loyalty and ideological loyalty. It portrays loyalty as a social phenomenon in which loyal customers feel connected with the company's other customers and with society in general. These customers have the greatest potential to make sense of their loyalty in an involved and engaged manner - to become apostles (Folkman Curasi and Kennedy, 2002) or members of a consumption community (McAlexander et al., 2002; Närvänen et al., 2019) .

\section{Discussion}

This study's findings portray a multifaceted and diverse view of customer loyalty; thus, they contribute to understanding customer loyalty from the customer's perspective (Folkman Curasi and Kennedy, 2002), but rather than typologise customers into loyalty categories, we build on a sensemaking perspective and show the context-bound and dynamic meaningmaking (Thompson, 1997) related to customer loyalty. For instance, meaning-making that involves binding loyalty may point to a very strong marriage-like relationship, but it also may be the first phase of a customer ending a loyal customer relationship because they feel too restricted. Thus, the retailer should identify this type of meaning-making to avoid losing loyal customers. Meaning-making relating to freedom-of-choice may be about multi-loyalty, as well as customers rationalising their behaviour to themselves and others, or about optimising purchasing decisions in a specific situation in their lives. However, customers also see loyalty very much as a mutual issue in which the company also needs to show loyalty to them and their values and interests. The loyalty-as-belongingness metaphor provides great potential through which retailers can build longer-lasting loyalties in, for instance, customer communities. 
Our findings enrich the current view of loyalty, which focuses on the company's view and often approaches loyalty as a dependent variable, comprising cognitive and behavioural aspects. The findings show that loyalty involves continuous negotiation and interpretation by consumers on the nature, content, conditions and stages of being loyal. This negotiation and interpretation take place through a plurality of cultural meanings, both private and social. Customers make sense of loyalty by connecting it with their life stories and identities (McAdams and McLean, 2013), as well as concrete experiences with retailers and their relationships with competitors, other consumers and the broader society and culture. To interpret these meanings, the interviewees utilised rich metaphors, such as comparing customer loyalty with human relationships, playing games or being in prison. Metaphors are fundamental in sensemaking, as they generate more mental imagery and help elaborate on aspects of phenomena through language (Gilliam and Rockwell, 2018). In conclusion, our analysis presents the loyalty phenomenon as reaching far beyond simple transactions or measurable indicators to more enduring, dynamic and temporal aspects of customer loyalty described through loyalty metaphors. It also highlights the consumer as an active subject and meaning-maker, rather than as a mere passive target of marketing actions within established loyalty programmes.

Dividing customer loyalty into attitudinal and behavioural components is relatively straightforward in terms of measuring customer loyalty and managing it from the retailer's perspective. However, our findings provide a totally new perspective to customer loyalty in the retail setting. Customers do not interpret behaviour and cognition as separate issues, but instead weave these aspects into their loyalty narratives in more complex and context-bound ways. Loyalty may be expressed by customers as a nexus of heterogeneous, context-specific meanings (Thompson, 1997). This highlights the importance of a deeper, more holistic understanding of customer loyalty that represents a next step in customer-loyalty management.

\subsection{Managerial implications}

Our findings provide several relevant insights for managers. The loyalty metaphors presented here can be viewed in the context of marketing and customer-relationship strategies, and we illustrate examples in Table 2.

Freedom-of-choice- and loyalty-as-convention-based sensemaking can be beneficial to support in the retailer's marketing communications by promoting customers' confidence in the choices that they have made and by highlighting how sensible and rational it is to be loyal. However, if these kinds of meanings are emphasised too much, customers may not feel a deep sense of emotional attachment to the retailer. Loyalty-as-binding-based sensemaking is potentially the most negative of the metaphors and, thus, contains several risks. While some consumers may find security and comfort in a binding relationship, for many, this type of sensemaking may not reach the loyalty level. Trust needs to be earned for the customer to feel that the relationship is mutual. To support other, more positive loyalty meanings, the retailer should avoid portraying the loyalty programme as too binding or restrictive for the customer. It is important for customers to feel like they are in control of their loyalty, instead of the retailer forcing it upon them. Finally, the loyalty-as-belongingness metaphor offers opportunities to build longer-lasting loyalty as it is connected to customers' values and relationships to each other. To support this type of sensemaking, the retailer could concentrate on leveraging its corporate social responsibility strategies in the loyalty programme and provide platforms for online and offline consumer-to-consumer interactions (Närvänen et al., 2019).

However, it is important to note that it was not our study's objective to classify the interviewees according to which loyalty type best described their situations or personal 
Loyalty metaphor

Loyalty is freedom of choice

Loyalty is conventional

Loyalty is binding

Loyalty as

belongingness
Examples of managerial implications

Offer variety and choice for customers to feel that they are in control and can choose freely

Seek customer feedback on the type of rewards and benefits they are seeking in order to optimise purchases

Acknowledge that customers are multi-loyal and members in various reward programmes

Use gamification to set goals and make it fun for customers to try to reach them

Develop in-store (brick and mortar) as well as omnichannel prizes and events

Utilise nostalgia and family values in marketing communications to promote

conventional loyalty

Make purchasing easy and safe for customers

Develop the store layout to provide support and familiarity for customers

Acknowledge that loyalty is a habit

Utilise the opportunity to get new customers by making them reconsider their conventions

Build trust in every interaction - loyalty is a continuous phenomenon that the retailer needs to earn

Avoid causing surprise disappointments for the customers

Reinforce the customer's feeling that they've made the right choice

Reinforce loyalty in personal interactions between personnel and customers

Identify customers who feel negatively about binding loyalty to avoid losing them

Develop customers' sense of community and togetherness by offering customer-to-

customer interaction platforms

Develop customer's sense of identification with the company by leveraging corporate social responsibility strategies

Make shared values more explicit in communications and the reward programme

Seek customers' ideas and co-create with them

\section{A meaning- based framework for customerloyalty}

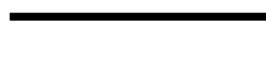

(Table

Table 2.

Examples of practical solutions for retailers

experiences. Instead, presenting and dimensionalising the multitude of different meanings that describe what customer loyalty means to customers were relevant in this study. Today's consumers have multiple roles, and their behaviour is highly context-dependent. Therefore, a single customer's behaviour may be characterised by a variety of loyalty meanings and types, depending on the situation. Thus, Table 2 aims to offer examples of solutions that can be proposed from the perspective of the alternative mind-set to customer loyalty that we present in the article. Adopting this more holistic mind-set, which goes beyond customer loyalty in the present time as attitudinal and behavioural, to consider it in the context of the customer's temporal loyalty narrative, comprising private and social meanings and metaphors, is important.

Retailers should aim to ensure that their loyal customers receive the kind of information, offerings and value that best serve them in any given context and situation. For the retailer to accomplish this, it needs to know more about what meanings are relevant and important for its loyal customers in different contexts. The dynamic and context-dependent nature of loyalty should be accepted and recognised. A balance should exist between making customers commit to the retailer and allowing them to choose freely. Our framework of loyalty meanings can be utilised in planning the retailer's marketing communications, rewarding customers through the loyalty programme, and training customer service employees to recognise the different kinds of sensemaking strategies that their customers may have.

Customer-loyalty meanings' complexity emphasises the need for rich customer insights to develop customer loyalty as a company's intangible asset. While data on customer loyalty, including data from surveys or focus groups, are used to build on purchase history to account for behavioural loyalty and understand the attitudinal component of loyalty (Kumar and 
Shah, 2004), many companies currently are rushing to exploit big data in building their customer-loyalty programmes (Grewal et al., 2017). Our study provides a reminder concerning the multifaceted and deep levels of understanding and contextual interpretations needed to build customer loyalty. Big data are undoubtedly highly efficient in helping companies target customers more accurately. Big data also can predict some behavioural patterns on a large scale based on data points generated about customers' behaviours. However, the levels of meaning that are highly significant in explaining customers' relationships with companies are also important. Customer loyalty, as shown in our study, is highly dependent on the customer's context and personal interpretations. Thus, the meaning-based view provides an alternative perspective that highlights deeper emotions and values of customer loyalty, beyond mere purchasing behaviour. Companies can use these meanings to build stories that engage customers at a more emotional level. Thus, the retailer's ability to engage in conversational marketing, in which customers' sense-making is listened to carefully and appreciated to tell the right story at the right time, is essential. One way to accomplish this is through social media, in which consumers' textual and visual narratives can be obtained and analysed for meanings and metaphors contained within them (Pantano and Gandini, 2018).

Obtaining these customer insights necessarily requires another type of data sometimes called thick data (Wang, 2016), which are rich in context, detail and narrative quality. This type of data is generated from a small sample of customers utilising anthropological and sociological research methods, such as ethnography or in-depth interviewing (Moisander et al., 2020). Companies need to invest in new capabilities that enable generation of these indepth insights. A further consideration is the loyalty programme's transparency. Instead of utilising the information only for the company's purposes, giving customers access to the insights that the company has obtained yields opportunities for both customer and company to learn more. Thus, customer data can be used for the customer's benefit (Saarijärvi et al., 2013) to enrich dialogue with customers and adopt a more customer-driven approach.

\subsection{Limitations and future research directions}

Like in any study conducted with qualitative research methodologies, this study's limitations include that the findings are contingent upon the study's context, time and place. The meanings of customer loyalty also have been identified in a particular context - in this case, Finland and Scandinavia. The sociocultural context always plays a role in meaning-making. It is not considered a weakness of the study as such, but it frames the interpretation of the findings and generates the need for further research. However, qualitative research's aim is not statistical generalisation, but rather the introduction of novel concepts and frameworks for thinking about customer loyalty in new ways (Gummesson, 2006). Thus, the findings' contingent nature can be overcome by testing them further using different types of methodologies. For instance, examining how consumers construct meanings for loyalty in different cultures and across different demographics presents an important future research opportunity. Companies' role in shifting meanings of customer loyalty through marketing actions or marketing communications is also worth studying further. An interesting perspective would be to investigate how the meaning-based view can be integrated into customer-loyalty programmes. Finally, achieving a holistic view of customer loyalty with the help of both big data and more interpretive, in-depth insights is relevant, but so far unexplored, territory.

\section{References}

Aksoy, L., Keiningham, T.L., Buoye, A., Larivière, B., Williams, L. and Wilson, I. (2015), "Does loyalty span domains? Examining the relationship between consumer loyalty, other loyalties and happiness", Journal of Business Research, Vol. 68 No. 12, pp. 2464-2476. 
Audrain-Pontevia, A. and Vanhuele, M. (2016), "Where do customer loyalties really lie, and why? Gender differences in store loyalty", International Journal of Retail and Distribution Management, Vol. 44 No. 8, pp. 799-813.

Blut, M., Beatty, S.E., Evanschitzky, H. and Brock, C. (2014), "The impact of service characteristics on the switching costs-customer loyalty link", Journal of Retailing, Vol. 90 No. 2, pp. 275-290.

Borghini, S., Diamond, N., Kozinets, R.V., McGrath, M.A., Muñiz, A.M. and Sherry, J.F. (2009), "Why are themed brandstores so powerful? Retail brand ideology at American girl place", Journal of Retailing, Vol. 85 No. 3, pp. 363-375.

Brown, A.D., Colville, I. and Pye, A. (2015), "Making sense of sensemaking in organization studies", Organization Studies, Vol. 36 No. 2, pp. 265-277.

Bruner, J.S. (1990), Acts of Meaning, Harvard University Press, Cambridge, MA, Vol. 3.

Chiu, H.C., Hsieh, Y.C. and Kuo, Y.C. (2012), "How to align your brand stories with your products", Journal of Retailing, Vol. 88 No. 2, pp. 262-275.

Creswell, J.W. (2007), Qualitative Inquiry and Research Method: Choosing Among Five Approaches, (2nd ed)., Sage, Thousand Oaks, CA.

Dick, A.S. and Basu, K. (1994), "Customer loyalty: toward an integrated conceptual framework", Journal of the Academy of Marketing Science, Vol. 22 No. 2, pp. 99-113.

Eisenhardt, K.M. and Graebner, M.E. (2007), "Theory building from cases: opportunities and challenges", Academy of Management Journal, Vol. 50 No. 1, pp. 25-32.

Folkman Curasi, C. and Kennedy, K. (2002), "From prisoners to apostles: a typology of repeat buyers and loyal customers in service business", Journal of Services Marketing, Vol. 16 No. 4, pp. 322-341.

Fraering, M. and Minor, M. (2013), "Beyond loyalty: customer satisfaction, loyalty, and fortitude", Journal of Services Marketing, Vol. 27 No. 4, pp. 334-344.

Gilliam, D.A. and Rockwell, C.C. (2018), "Stories and metaphors in retail selling”, International Journal of Retail and Distribution Management, Vol. 46 No. 6, pp. 545-559.

Gilliam, D.A. and Zablah, A.R. (2013), "Storytelling during retail sales encounters", Journal of Retailing and Consumer Services, Vol. 20 No. 5, pp. 488-494.

Gioia, D.A., Corley, K.G. and Hamilton, A.L. (2013), "Seeking qualitative rigor in inductive research: notes on the Gioia methodology", Organizational Research Methods, Vol. 16 No. 1, pp. 15-31.

Glaser, B.G. and Strauss, A.L. (1967), The Discovery of Grounded Theory: Strategies for Qualitative Research, Aldine Publishing Company, Chicago, IL.

Grewal, D., Roggeveen and Nordfält, J. (2017), "The future of retailing”, Journal of Retailing, Vol. 93 No. 1, pp. 1-6.

Gummesson, E. (2006), "Qualitative research in management: addressing complexity, context and persona”, Management Decision, Vol. 44 No. 2, pp. 167-179.

Harris, P. (2017), "Multichannel shopping well-being: a narrative-based examination", Qualitative Market Research: An International Journal, Vol. 20 No. 3, pp. 354-369.

Kozinets, R.V., Sherry, J.F., DeBerry-Spence, B., Duhachek, A., Nuttavuthisit, K. and Storm, D. (2002), "Themed flagship brand stores in the new millennium: theory, practice, prospects", Journal of Retailing, Vol. 78 No. 1, pp. 17-29.

Kumar, V. and Shah, D. (2004), "Building and sustaining profitable customer loyalty for the 21st century”, Journal of Retailing, Vol. 80 No. 4, pp. 317-329.

Kumar, V., Sharma, A., Shah, R. and Rajan, B. (2013), "Establishing profitable customer loyalty for multinational companies in the emerging economies: a conceptual framework", Journal of International Marketing, Vol. 21 No. 1, pp. 57-80.

Liu-Thompkins, Y. and Tam, L. (2013), "Not all repeat customers are the same: designing effective cross-selling promotion on the basis of attitudinal loyalty and habit", Journal of Marketing, Vol. 77 No. 5, pp. 21-36. 
McAdams, D.P. and McLean, K.C. (2013), "Narrative identity", Current Directions in Psychological Science, Vol. 22 No. 3, pp. 233-238.

McAlexander, J.H., Schouten, J.W. and Koenig, H.F. (2002), "Building brand community", Journal of Marketing, Vol. 66 No. 1, pp. 38-54.

Moisander, J., Närvänen, E. and Valtonen, A. (2020), "Interpretive marketing research: using ethnography in strategic market development", in Visconti, L.M., Peñaloza, L. and Toulouse, N. (Eds), Marketing Management: A Cultural Perspective, 2nd ed., Routledge, London.

Närvänen, E., Koivisto, P. and Kuusela, H. (2019), "Managing consumption communities”, Journal of Strategic Marketing, Vol. 27 No. 5, pp. 388-404.

Nastasoiu, A. and Vandenbosch, M. (2019), "Competing with loyalty: how to design successful customer loyalty reward programs”, Business Horizons, Vol. 62 No. 2, pp. 207-214.

Ngobo, P.V. (2017), "The trajectory of customer loyalty: an empirical test of Dick and Basu's loyalty framework", Journal of the Academy of Marketing Science, Vol. 45 No. 2, pp. 229-250.

Nyadzayo, M.W. and Khajehzadeh, S. (2016), "The antecedents of customer loyalty: a moderated mediation model of customer relationship management quality and brand image", Journal of Retailing and Consumer Services, Vol. 30, pp. 262-270.

Oliver, R.L. (1999), “Whence consumer loyalty?”, Journal of Marketing, Vol. 63, Special Issue, pp. 33-44.

Oliver, R.L. (2010), Satisfaction: A Behavioral Perspective on the Consumer, 2nd ed., M.E. Sharpe, Armonk, NY.

Olsen, S.O., Tudoran, A.A., Brunsø, K. and Verbeke, W. (2013), "Extending the prevalent consumer loyalty modelling: the role of habit strength", European Journal of Marketing, Vol. 47 No. 1, pp. 303-323.

Orth, U.R. and Green, M.T. (2009), "Consumer loyalty to family versus non-family business: the roles of store image, trust and satisfaction", Journal of Retailing and Consumer Services, Vol. 16 No. 4, pp. 248-259.

Pan, Y., Sheng, S. and Xie, F.T. (2012), “Antecedents of customer loyalty: an empirical synthesis and re-examination”, Journal of Retailing and Consumer Services, Vol. 19 No. 1, pp. 150-158.

Pantano, E. and Gandini, A. (2018), "Shopping as a "networked experience": an emerging framework in the retail industry", International Journal of Retail and Distribution Management, Vol. 46 No. 7 , pp. 690-704.

Polkinghorne, D.E. (1988), Narrative Knowing and the Human Sciences, SUNY Press, Albany.

Richins, M.L. (1994), "Valuing things: the public and private meanings of possessions", Journal of Consumer Research, Vol. 21 No. 3, pp. 504-521.

Rundle-Thiele, S. (2005), "Elaborating customer loyalty: exploring loyalty to wine retailers", Journal of Retailing and Consumer Services, Vol. 12 No. 5, pp. 333-344.

Saarijärvi, H., Karjaluoto, H. and Kuusela, H. (2013), "Customer relationship management: the evolving role of customer data”, Marketing Intelligence and Planning, Vol. 31 No. 6, pp. 584-600.

Sirohi, N., McLaughlin, E.W. and Wittink, D.R. (1998), "A model of consumer perceptions and store loyalty intentions for a supermarket retailer", Journal of Retailing, Vol. 74 No. 2, pp. 223-245.

So, K., King, C., Sparks, B. and Wang, Y. (2016), "Enhancing customer relationships with retail service brands: the role of customer engagement", Journal of Service Management, Vol. 27 No. 2, pp. $170-193$.

Thompson, C.J. (1997), "Interpreting consumers: a hermeneutical framework for deriving marketing insights from the texts of consumers' consumption stories", Journal of Marketing Research, Vol. 34 No. 4, pp. 438-455.

Töytäri, P., Rajala, R. and Alejandro, T.B. (2015), "Organizational and institutional barriers to valuebased pricing in industrial relationships", Industrial Marketing Management, Vol. 47, pp. 53-64. 
Umashankar, N., Bhagwat, Y. and Kumar, V. (2017), "Do loyal customers really pay more for services?", Journal of the Academy of Marketing Science, Vol. 45 No. 6, pp. 807-826.

Uncles, M.D., Dowling, G.R. and Hammond, K. (2003), "Customer loyalty and customer loyalty programs", Journal of Consumer Marketing, Vol. 20 No. 4, pp. 294-316.

Vilches-Montero, S., Pandit, A., Bravo-Olavarria, R. and Chao, C.W.F. (2018), "What loyal women (and men) want: the role of gender and loyalty program characteristics in driving store loyalty", Journal of Retailing and Consumer Services, Vol. 44, pp. 64-70.

Wang, T. (2016), "Why big data needs thick data", available at: https://medium.com/ethnographymatters/why-big-data-needs-thick-data-b4b3e75e3d7 (accessed 19 November 2018).

Watson, G.F., Beck, J.T., Henderson, C.M. and Palmatier, R.W. (2015), "Building, measuring, and profiting from customer loyalty", Journal of the Academy of Marketing Science, Vol. 43 No. 6, pp. 790-825.

Weick, K.E. (1995), Sensemaking in Organizations, Sage, Thousand Oaks, CA.

Wolter, J.S., Bock, D., Smith, J.S. and Cronin, J.J. (2017), "Creating ultimate customer loyalty through loyalty conviction and customer-company identification", Journal of Retailing, Vol. 93 No. 4, pp. $458-476$.

Woodside, A. (2001), "Sense making in marketing organizations and consumer psychology: theory and practice", Psychology and Marketing, Vol. 18 No. 5, pp. 415-421.

Woodside, A.G. (2010), "Brand-consumer storytelling theory and research: introduction to a Psychology and Marketing special issue”, Psychology and Marketing, Vol. 27 No. 6, pp. 531-540.

Yoo, M. and Bai, B. (2013), "Customer loyalty marketing research: a comparative approach between hospitality and business journals", International Journal of Hospitality Management, Vol. 33, pp. 166-177.

YouGov (2018), "Affluent consumer attitude towards brand loyalty worldwide as of March 2017, by region", available at: https://www.statista.com/statistics/788788/affluent-consumer-attitudebrand-loyalty/ (accessed 27 November 2018).

\section{Corresponding author}

Elina Närvänen can be contacted at: elina.narvanen@tuni.fi

For instructions on how to order reprints of this article, please visit our website:

www.emeraldgrouppublishing.com/licensing/reprints.htm

Or contact us for further details: permissions@emeraldinsight.com 